UDC 5308:004

\author{
${ }^{2}$ K.B.Tlebaev", ${ }^{1}$ A.I. Kupchishin \\ ${ }^{1}$ Institute of New Chemical Technologies and Materials, Kazakhstan, Almaty \\ ${ }^{2}$ Abai Kazakh National Pedagogical University, Kazakhstan, Almaty \\ *E-mail: Tlebaev@mail.ru
}

\title{
Development of scientific basis of obtaining technology and study the properties of dielectric materials based on polymers and ionic crystals with the use of irradiation
}

\begin{abstract}
The scientific and methodological fundamentals of new composite materials were developed, as well as the experimental studies depending on stress-strain and thermal properties of the various polymers, dielectrics $(\mathrm{KBr}, \mathrm{KCL}$, etc.) and their compositions using irradiation. The most interesting results were obtained for polymers, in particular for polytetrafluoroethylene at the various temperatures 0,19 and $50^{\circ} \mathrm{C}$.

Key words: polymer, ionic crystals, dielectrics, composite, stress-strain, thermal properties, irradiation.

К. Б. Тлебаев, А.И. Купчишин

Разработка научных основ технологии получения и исследование свойств диэлектрических материалов на основе полимеров и ионных кристаллов с использованием облучения
\end{abstract}

Разработаны научно-методические основы получения новых композитных материалов, а также проведены экспериментальные исследования по зависимости напряжения от деформации и тепловых свойств для различных полимеров, диэлектриков (KBr, KCL, и др.) и их композиций с использованием облучения. Наиболее интересные результаты получены на полимерах, в частности на политетрафторэтилене при различных температурах 0,19 и $50^{\circ} \mathrm{C}$.

Ключевые слова: полимер, ионный кристалл, диэлектрики, композит, деформация, термические свойства, облучение.

Қ.Б. Тілебаев, А.И. Купчишин

Сәулелендіруді пайдалана отырып иондық кристалдардың және полимерлердің негізінде диэлектрлік материалдардың қасиетін зерттеу және алу технологияларының ғылыми негізін құрастыру

Жаңа композиттік материалдарды алудың жаңа ғылыми-методикалық негізі құрастырылды, сонымен қатар әртүрлі полимерлер, диэлектриктер (KBr, KCL және т.б..) үшін және олардың компазициясына сәулелендіруді қолдана отырып, ток күшіне байланысты деформациясы және жылулық қасиеті тәжірибе жүзінде зерттелінді. Маңыздылығы жоғары нәтижелер әртүрлі температурада 0, 19 және 50 С политетрафторэтилен полимерінде алынды.

Түйін сөздер: полимер, иондық кристалл, диэлектриктер, композит, деформация, термиялық қасиеттер, сәулелену.

\section{Introduction}

The polymeric materials (polyester resin, polytetrafluoroethylene, polyethylene, polyimides, polymeric coatings etc.) and insulators $(\mathrm{KBr}, \mathrm{KCl}$ etc.) have already become a model for the study of mechanisms of unstressed a primary radiation defects and the accumulation of secondary processes, complex (up to the colloids) defects in the bulk of a solid when exposed to ionizing radiation.

No less important is the role of these materials for the study of radiation-simulated phenomena. One such important for the science and practice of phenomena is the formation of these materials in the form of macroscopic defects of radiated crystals (RC) under the influence of gamma and electron radiation.

As it has appeared the exposure to ionizing radiation of the "polymer-dielectric-air" leads to an effective change of structure and properties, even when compared with the radiation damage in the crystals. 
Under the conditions of contact crystals $\mathrm{KBr}$, $\mathrm{KCl}$ with the atmosphere at the surface of crystalline phases are created nitrates and oxyhalides alkali metals. The heterogeneous nature of the phenomenon is confirmed by that with the increase of the specific surface of the samples occurs increasing depth of the layer of reaction products.

These radiation-chemical technologies were based on the use of accelerators of charged particles (electrons and ions) as well as data of neutron nuclear reactors and nuclear power plants, due to the need to obtain materials with desired physical and chemical properties.

In this regard, the problems were considered associated with the passage of particles through matter, their interaction with condensed media and on this basis - getting materials with desired properties and prediction of these properties. To these used materials the strict requirements are imposed, as they often work in extreme conditions of the intense radiation fluxes, the high mechanical stresses, high temperatures and pressures and corrosive environments. According to the type and energy of the incident particles, the atomic number of the target, the temperature of the material, etc. in solids are taken place the different rather complex processes ranging from the interaction of primary particles with electrons and atoms of the medium, and scattering of particles, the excitation of atoms and nuclei, and the formation of primary and secondary-sputtered atoms (PVA-BBA, respectively) and finishing by the phase transitions, anomalous phenomena, exotic effects [1-4].

The problem of obtaining new composites, especially those with structural and phase transformations in the polymer has recently become extremely important.

The necessity of such work is caused by the need of development of this field in the world in general, as well as in Kazakhstan and is due to the demand in new materials and solution to stabilize the structure and properties of materials under conditions of the intense radiation, creating radiation technology, the production of materials with desired properties, the use of radiation in the industry of Kazakhstan. It has already now on the basis of the previous studies in the 2al-Farabi Kazakh National University and FTTS the introduction of the results is going to the JSC "Medpolimer", "Polymed", "Unimed", "Bios", "Antarius", "Doltse" LLP, "Kama", etc.

It is due to the fact that in addition to the well- known type of fusion reactions and glass, for example in the irradiated polytetrafluoroethylene (PTFE), we found another type of structural transformation at room temperature, the interpretation of which has been defined a significant interest in its investigation. However, not all researchers are of the single point of view regarding the domain of these transitions, mainly is due to the fact that different methods are used. The "Static" measurements are usually given a low temperature for the same transition than dynamic (mechanical, dielectric and NMR). In the measurements by dynamic methods with increasing frequency, the transition point is shifted to higher temperatures. Further confuses the issue is the fact that static methods can sometimes show the existence of the transition that are not detected by dynamic methods and vice versa. For example, the phase transitions of PTFE at room temperature are very clearly manifested in the calorimetric measurements and by X-ray diffraction analysis. It should also be noted that the simultaneous measurement of mechanical and thermal properties of polymers were not carried out.

Thus, at present there are some contradictions between the various authors of the synthesis of new composites, the existence and nature of structural transformations in them.

\section{Experiment}

The irradiation of composite was carried out on the electron accelerator of the type ELU-6 with the intensity of a beam of particles (current) from 0.1 to $0.5 \mu \mathrm{A}$, with the energy of $4-\mathrm{MeV}$ up to the integral doses 102-104 Gy. It was found that the electron irradiation at the energies of the particles in the studied range $2-6 \mathrm{MeV}$ is significantly strengthened the composite, due to the additional cross-linking of the polymer binder with the components of the composite.

The samples of dielectrics have being pulverized at a special mill to micro and nano scale. Then the components were mixed in a predetermined ratio. Thereafter the mixture was poured polyester resin with hardener and poured into a form and pressed. The samples were dried for 20-50 hours, depending on the assumed properties of the composite.

The tensile strength of PTFE materials was tested for tensile testing machine. The samples with a working length $a=50 \mathrm{~mm}$ and width $b=5$ $\mathrm{mm}$ were deformed in uniaxial tension mode for 
experimental computer installation created by us based on the tensile testing machine model RMU-0, 05 - 1 with the appropriate software in a standard Windows - applications. The obtained experimental data were transmitted directly to the table EXCEL. The mechanical testing of the materials were manufactured according to GOST 14236-81 and GOST 11262-80 at three temperatures $\mathrm{T}_{1}=00 \mathrm{C}$, $\mathrm{T}_{2}=190 \mathrm{C}$ and $\mathrm{T}_{3}=500 \mathrm{C}$ and the speed of the film moving apart grippers 36, $09 \pm 0,05 \% \mathrm{~mm} / \mathrm{min}$. And capture movement associated with the meter did not exceed $0.1 \mathrm{~mm}$. The temperature of the samples was maintained with the help of a special device.

\section{Results and Discussion}

The scientific and methodological fundamentals for obtaining of new composite materials were developed and the experimental studies of the electrical properties (conductivity, dielectric properties, breakdown, etc.) polymer (polyester resin, polytetrafluoroethylene, polyethylene terephthalate, polyimide, polymeric coatings, etc.) and insulators (KBr, KCL, etc.) with the use of irradiation were carried out.

The detailed analysis of the state the issue on the subject in question was carried out, in particular on the development of technologies for producing ionic crystals, including materials such as potassium chloride, potassium bromide, sodium chloride, sodium bromide, carbon dioxide, aluminum, etc. It was found that in the literature there are quite a lot of research on the effects of different types of radiation on the physical and chemical properties and structure of ionic crystals (especially the optical properties of materials). It was revealed that among other things the beams of charged and neutral particles are used widely in industry, medicine, agriculture, engineering, etc.

The technology was developed for production of new materials using polymers (polyester resin, polytetrafluoroethylene, polyethylene terephthalate, polyimide, etc.) and insulators ( $\mathrm{KBr}, \mathrm{KCL}$, etc.). The technology for producing a new material includes a selection of the components and their concentrations, the grinding components with a special setup, the sifting powdered material, the mixing of the components in the specified proportion, the processing of the electron and ion beams and manufacture of the experimental samples (pressing, sintering, cooling, grinding, polishing materials for fixed physical, chemical and technological parameters and different actions).

The appropriate chemical and engineering and radiation modes of production (the concentrations of filler, intensity, energy and dose) of the composites were developed.

It was found that the parameters of the manufactured composite and the manufacturing technology of the new materials based on dielectric metal particles is strongly depended on the size and structure of the components of mixed materials, their compatibility and external influences.

The experimental study of the electrical properties (conductivity, dielectric properties, breakdown, etc.), polymer (polyester resin, polytetrafluoroethylene, polyethylene terephthalate, polyimide, etc.) and insulators ( $\mathrm{KBr}, \mathrm{KCL}$, etc.), with the inclusion of the nanomaterials of nano metal particles of the nano powders $\mathrm{Al}$, etc., applied coatings at different intensities directly under a beam of high-energy electrons were carried out. It was found that the tested properties depend strongly on the exposure and especially the intensity and dose, with increasing of them the electrical properties under the beam can be changed more than ten times.

The scientific basis of the technology was developed and prototypes were manufactured. In the study of composites based on polytetrafluoroethylene, for example, it was taken into account that the polymer has a phase transition in the temperature range of $19-30{ }^{\circ} \mathrm{C}$. Moreover, we have shown that, thermal and other properties of this material depend strongly on the energy and dose of the electron irradiation (thermal conductivity, specific heat, thermal conductivity, thermal expansion coefficient, electrical and mechanical properties, and so on) (table 1 and figure1-4). With increasing doses of the peak value is reduced, and the peak shifts to the left and then disappears altogether. At low concentrations of the second component the phase transition is partially the case. Adding a second component in the mixture, as in the case of the electron irradiation is reduced the amplitude of the peak and shifts it to lower temperatures. The effect of electron irradiation on the mechanical properties of insulators for continuous and pulsed high-intensity electron beams was studied. 
Table 1 - The experimental values of the temperature dependence of the thermal conductivity of PTFE under different doses of electron irradiations

\begin{tabular}{|c|c|c|c|c|}
\hline \multirow{3}{*}{$\mathrm{T}, \mathrm{K}$} & \multicolumn{3}{|c|}{$\lambda, \mathrm{W} / \mathrm{m} \cdot \mathrm{K}$} \\
\cline { 2 - 5 } 240 & $\mathrm{D}=0, \mathrm{MGy}$ & $\mathrm{D}=0.05, \mathrm{MGy}$ & $\mathrm{D}=1, \mathrm{MGy}$ & $\mathrm{D}=2, \mathrm{MGy}$ \\
\cline { 2 - 5 } 260 & 0.295 & 0.300 & 0.303 & 0.280 \\
\cline { 2 - 5 } 280 & 0.301 & 0.308 & 0.312 & 0.280 \\
\cline { 2 - 5 } 293 & 0.308 & 0.325 & 0.319 & 0.282 \\
\hline 303 & 0.320 & 0.300 & 0.289 & 0.282 \\
\hline 320 & 0.301 & 0.290 & 0.290 & 0.282 \\
\cline { 2 - 5 } 330 & 0.303 & 0.303 & 0.303 & 0.305 \\
\hline
\end{tabular}

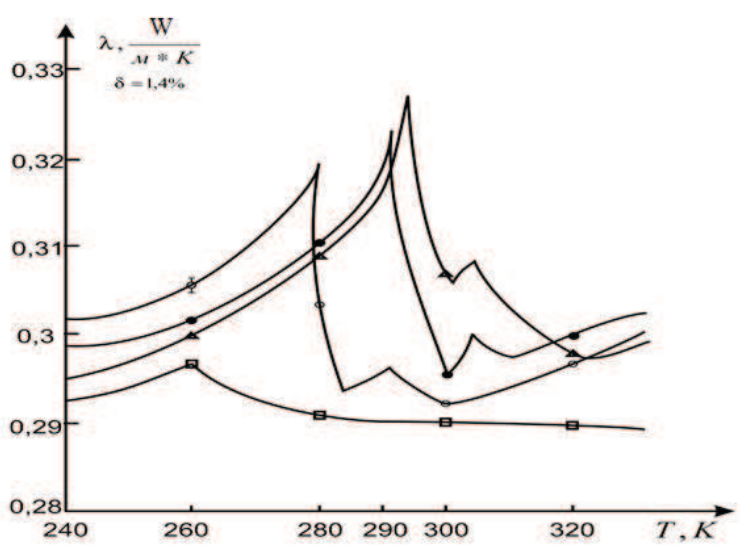

The absorbed dose D: $(\boldsymbol{\Delta})-0 ;(\bullet)$ - 0.05; (०) - 1; (口) MGy-2

Figure 1 - Dependence of the thermal conductivity of PTFE on the temperature measurement

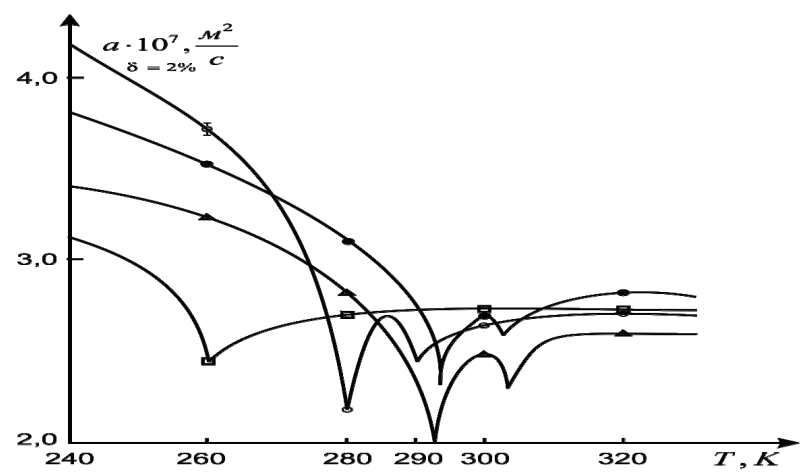

The absorbed dose D: $(\boldsymbol{\Delta})-0 ;(\bullet)-0.05 ;(\circ)-1 ;(\square)$ - MGy-2

Figure 3 - The dependence of the thermal diffusivity of PTFE on the temperature measurement

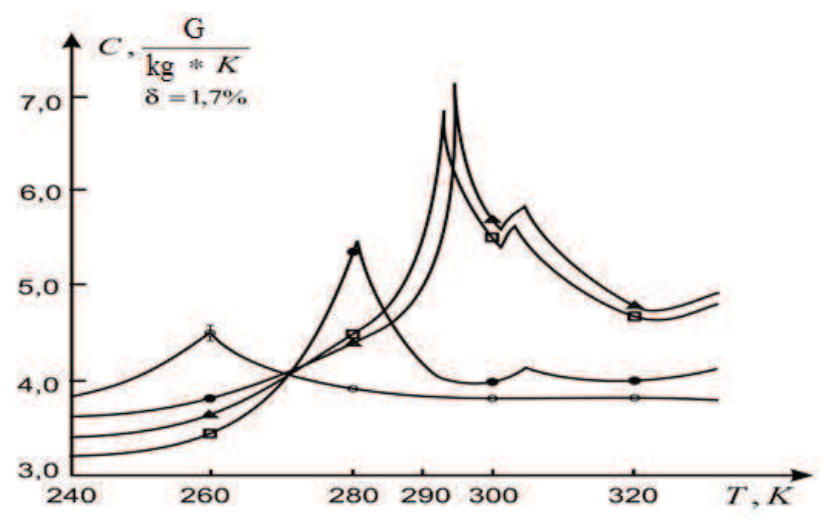

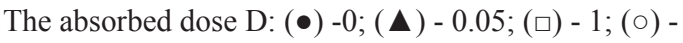
MGy-2

Figure 2 - The dependence of the specific heat of PTFE on the temperature measurement

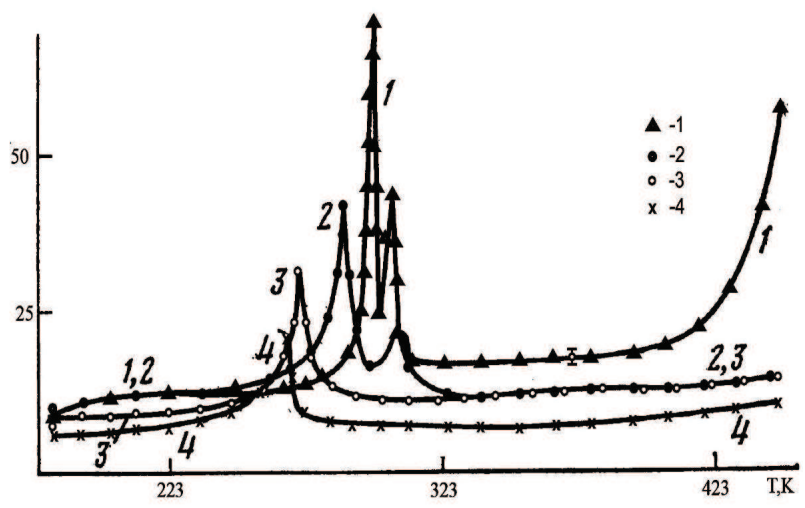

The absorbed doseD: $1-0,2-0.05,3-1, \mathrm{MG} 4-3$.

Figure 4 - The dependence of the coefficient of linear thermal expansion $\beta$ of PTFE on the temperature measurement 
The studies were carried out on the stressstrain and thermal properties of various polymers, dielectrics, and their compositions. The most interesting results were obtained for polymers (in particular polytetrafluoroethylene) at different temperatures $\left(0^{\circ}, 19^{\circ}\right.$ and $\left.50^{\circ} \mathrm{C}\right)$ (figure 5).

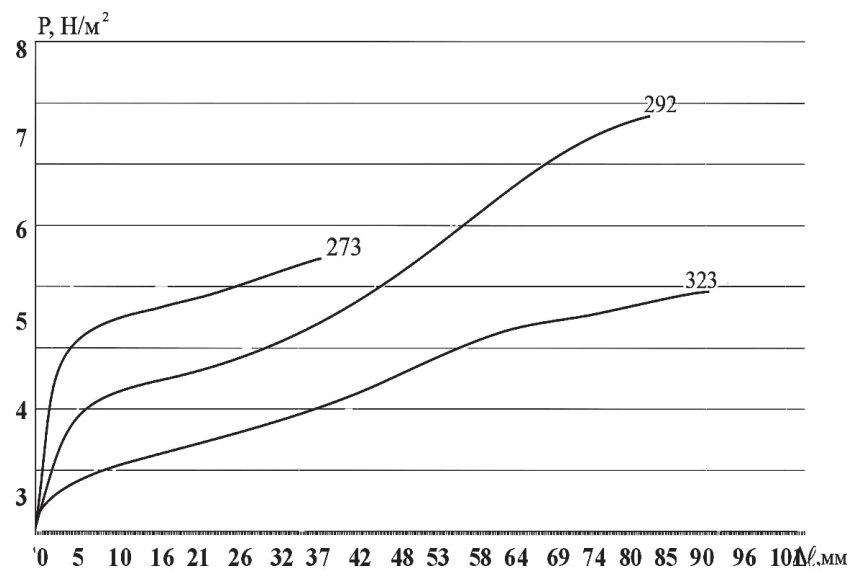

Figure 5-Curves of stress-strain at different temperatures

As follows from the experiments on all three curves were observed the anomalies at the room temperature, expressed as a sudden change for the specific heat and the coefficient of linear expansion, and in the form of bending tensile strength. Moreover, the temperature dependence of the specific heat was showed two peaks at the temperatures of $19^{\circ} \mathrm{C}$ and $30^{\circ} \mathrm{C}$, and the curve of the coefficient of linear expansion, in contrast to the curves of the specific heat was observed a single peak at $30^{\circ} \mathrm{C}$, which was more pronounced than on the curves.

\section{Conclusion}

From the study of composites based on polytetrafluoroethylene it is seen that the PTFE has a phase transition in the temperature range of 19$30^{\circ} \mathrm{C}$. Moreover, it was shown that, thermal and other properties of this material depend strongly on the energy and dose of the electron irradiation(thermal conductivity, specific heat, thermal conductivity, thermal expansion coefficient, electrical and mechanical properties, and so on).With increasing doses of the peak value is reduced, and the peak shifts to the left and then disappears altogether. At low concentrations of the second component the phase transition is partially the case. Adding a second component in the mixture, as in the case of the electron irradiation is reduced the amplitude of the peak and shifts it to lower temperatures.

The test results of PTFE films in tension at various temperatures show that at $\mathrm{T}=0^{\circ} \mathrm{C}$, a sharp drop intension and low elongation. The structural transition at $\mathrm{T}=19^{\circ} \mathrm{C}$, pronounced on the heat capacity curves of PTFE did not forma "neck" in tension and evenly pulled up to several hundred percent. At $\mathrm{T}=50^{\circ} \mathrm{C}$ occurred data uniform, smooth draw. The similar effects were observed in composite materials with a low concentration of the second component.

\section{References}

1 Gladyshev G.E. The influence of impurities on the radiation resistance of lead chloride, potassium // Phys. - 2006. - Vol.46, №.10. - P.1784-1785.

2 Savintsev A.P. Optical surface damage sodium and potassium by fem to second laser pulses // Technical Physics Letters. - 2008.Vol.34, №. 3. - P.66-69.

3 Gerdt A.P., Stas I.E., Aksenov N.V. The influence of high-frequency electromagnetic field on the properties of solutions of alkali metal chlorides // Proceedings of the ASP. - 2010. - №. 3-2 (67). - Chemistry Section. - P.141-145.

4 Eremin I., Scherban D.S. Modeling of elastic ion polarization crystal of potassium bromide // Cybernetic Physics. - 2012. № 1 (31). - P.124-128. 